\title{
A TRADUÇÃO COMO ATO POLÍTICO: DR. DOMINGOS JAGUARIBE E O MANUAL DE INSTRUÇÃO CÍVICA, DE NUMA DROZ'
}

\author{
Cleber Santos Vieira \\ Universidade São Francisco, Programa de Mestrado em Educação
}

\section{Resumo}

Neste artigo analisamos traduções de manuais escolares de civismo publicados nos primeiros anos do regime republicano brasileiro. Enfoca-se, sobretudo, a trajetória política do dr. Domingos Nogueira Jaguaribe Filho, tradutor do Manual de Instrução Cívica originalmente escrito pelo suíço Numa Droz. Parte-se do princípio de que os prefácios realçam as circunstâncias sociais que, articuladas à história da educação, trilham os sentidos dos protocolos de leitura, fazendo deles elementos singulares na análise do livro. Através dos prefácios podem-se ler, com maior amplitude, as flutuações na ideia de cidadania, variável que configura a formação cívica dos estudantes.

\section{Pallavras-chave}

prefácios • educação cívica • manuais escolares.

\section{Abstract}

This subject analyses the translations of the school manuals (school-books) published in the early years of Brazilian Republic system. It starts considering that the translation constituted an important way of participation into the direction of political history. Special attention is designed for the trajectory of dr. Domingos Nogueira Jaguaribe Filho, translator of Civic Education Instruction, by the Swiss Numa Droz. Such transposition represented a real political action since it confirmed the municipality as one of expectation for a political organization formulated in such context.

\section{Keywords}

cultural translation $\bullet$ civic education $\bullet$ school-books.

\footnotetext{
${ }^{1}$ Esse artigo é parte da tese Entre as coisas do mundo e o mundo dos livros: prefácios cívicos e impressos escolares no Brasil republicano, defendida junto ao Programa de Pós-Graduação da Faculdade de Educação da USP, sob orientação do prof. dr. Nelson Schapochnik.
} 
A imitação dos padrões culturais europeus como guia dos processos, projetos e programas de remodelação do panorama social brasileiro foi um traço marcante na história do país durante o século XIX. Em texto clássico, Roberto Schwarz ${ }^{2}$ demonstrou como a tentativa de transferir o modelo europeu afirmouse nos discursos e práticas sociais dos políticos e intelectuais que atuaram na construção e representação da imagem de um Brasil sincronizado com os ideais de progresso e civilização que pautaram a história do mundo ocidental daquele período. Para esse autor, a realidade histórica de uma sociedade escravista recebeu o lustre das mais avançadas ideias política da época. As tentativas de transplantar o liberalismo e algumas de suas variantes europeias no Brasil soaram como ideias fora do lugar. Os princípios de igualdade, liberdade e democracia, que pavimentavam as instituições liberais e o capitalismo industrial na Europa, no Brasil conviveram com o trabalho escravo e com a acentuada centralização política. Referindo-se ao comentário de Sérgio Buarque de Holanda publicado em Raízes do Brasil, Schwarz destacará este traço da vida ideológica brasileira como impropriedade de pensamento, pois, conforme afirmou Sérgio Buarque "trazendo de países distantes nossas formas de vida, nossas instituições e nossa visão de mundo, e timbrando em manter tudo isso em ambiente muitas vezes desfavorável e hostil, somos uns desterrados em nossa própria terra". ${ }^{3}$

Neste artigo, apresentamos a história da tradução do livro Manual de Instrução Cívica, de Numa Droz, como um componente desta equação. Trata-se de apresentar a ação do tradutor, Domingos Jaguaribe Filho, como ato que extrapolou a tentativa de tornar inteligível ao público leitor brasileiro um livro escrito em outro idioma. No ato de traduzir determinados princípios municipalistas de ordenação social e política do Estado republicano, estava explícito o desejo de intervir na modelação da vida política brasileira tendo por foco elementos da cultura europeia.

Ao analisar como a tradução de um livro interveio no processo de construção da ordem republicana, o texto aqui apresentado discute em que medida esta tradução assume feições peculiares, apresentando-se também como apropriação cultural. Assim, nas pegadas de Roger Chartier, entendemos a história desta tradução como estudo das práticas sociais que envolvem a produção e circulação do impresso. Nesta história, "a ênfase nas apropriações culturais também nos

\footnotetext{
${ }^{2}$ SCHWARZ, Roberto. As ideias fora do lugar. In: Cultura e política. $2^{\mathrm{a}}$ ed. Rio de Janeiro: Paz e Terra, 2005, p. 59-83.

${ }^{3}$ HOLANDA, Sérgio Buarque. Raizes do Brasil.18a ed. Rio de Janeiro: José Olympio, 1984, p. 03.
} 
permite ver que os textos ou as palavras destinadas a configurar pensamentos e ações nunca são inteiramente eficazes e radicalmente aculturadores". ${ }^{4}$ No caso das palavras de Numa Droz, traduzidas em língua portuguesa por dr. Domingos Jaguaribe Filho, significa pensar que a força das ideias municipalistas produzidas no bojo da cultura helvética, apropriadas como mecanismo de educação cívica e plataforma política, estacionou nos limites da história política brasileira.

O período histórico compreendido entre o fim da Monarquia e o início da República suscitou diferentes possibilidades quanto aos caminhos que levariam à consolidação do novo regime e quanto ao modelo de participação política a ser adotado como pedra de toque da cidadania. Nos gabinetes e escritórios das lideranças políticas republicanas, buscavam-se modelos adequados para formar o cidadão, incitando algumas publicações por parte do governo federal. Eram livros de inspiração estrangeira que, de alguma forma, revelavam as ideias cívicas que pairaram na cabeça de importantes protagonistas do regime instaurado em 1889.

Republicanos mostravam-se em plena sincronia com o que acontecia na Europa. No núcleo de poder instaurado no Estado de São Paulo ${ }^{5}$ circularam, por exemplo, as ideias de Jules Simon, ${ }^{6}$ ministro da Educação na França em 1873. Outro autor que influenciou os republicanos paulistas foi Paul Bert, nome que, ao lado de Jules Ferry, destacou-se como um dos mais proeminente na implantação da escola laica, pública e gratuita na França. Por aqui circulou particularmente a conferência em defesa da educação cívica, pronunciada em agosto de $1882 .^{7}$ Estas práticas de leitura indicavam interesse ante as transformações na esfera escolar ocorridas na França, desde o pensamento dos revolucionários de 1789, até as medidas executadas nas décadas seguintes, visando à universalização da instrução popular.

Outra prática usual entre aqueles que buscavam (re)definir a formação do cidadão brasileiro consistiu na tradução de manuais escolares de civismo. Os prefácios $^{8}$ de alguns desses livros revelam os caminhos percorridos por deter-

\footnotetext{
${ }^{4}$ CHARTIER, Roger. Texto, impressão, leituras. In: HUNT, Lynn. A nova história cultural. São Paulo: Martins Fontes, 1992, p. 233.

${ }^{5}$ É o que revela, por exemplo, o livros pertencentes a Prudente de Morais: GLEZER, Raquel (coord.). Catálogos do gabinete de trabalho de Prudente de Morais. São Paulo: Polo Editora, 2003. ${ }^{6}$ CARNOT, Havin; SIMON, Jules. L'instruction populaire en France. Paris: Biblioteque Liberale, 1877. ${ }^{7}$ BERT, Paul. L'education civique. Paris: Libraire Picard; Berheim, 1882.

${ }^{8}$ Neste artigo, a categoria prefácios será entendida a partir das considerações de Gérard Genette, ou seja "toda espécie de texto liminar (preliminar o pos liminar) autoral o alógrafo que constituye un discurso producido a propósito del texto que sigue o que precede". GENNETE, Gérard.
} 
minadas ideias até chegarem aos bancos escolares. Revelam, por exemplo, que a iniciativa partiu de vários flancos sociais e, para a publicação, contou com as máquinas tipográficas da Casa da Moeda, subordinada ao Ministério da Fazenda, chefiado por Rui Barbosa. O próprio Rui foi tradutor do livro norte-americano Lições de coisas, de N. A Calkins. ${ }^{9}$ Em estudo realizado sobre Rui Barbosa tradutor, Luciano Mendes de Faria Filho ressaltou o empenho e as dificuldades do ministro para convencer o governo brasileiro a arcar com as despesas de tradução, impressão e distribuição do "seu" Lições de coisas. Relatou ainda que a prática da tradução poderia ter motivações diversas, a saber: retorno financeiro, estratégia de divulgação de determinado conhecimento ou de lançar novas perspectivas ao fenômeno educativo. Lançou ainda pistas importantes para a análise das traduções de livros didáticos, particularmente ao encaminhar a possibilidade de se trabalhar com as categorias traduções culturais e traduções de culturas escolares na análise dos textos pedagógicos.

No caso de Rui Barbosa tratou-se de influenciar na reorganização dos conteúdos e métodos de ensino de uma disciplina escolar específica, Lições de coisas. Conforme assinalou Luciano Farias Filho, traduzir significou esquadrinhar o texto, adaptar, subtrair passagens consideradas demasiadamente específicas ao sistema de ensino norte-americano e, portanto, de reduzidas chances de compreensão entre o público escolar brasileiro. Todavia, a Casa da Moeda promoveu a tradução de impressos escolares cuja centralidade deve ser buscada menos nas questões pedagógicas e mais nos elos que relacionavam educação, política e tradução como ato político. Nesse sentido, faz-se necessário alargar as referências conceituais e incidir sobre o papel desempenhado pelo livro na conformação da sociedade planejada pelos ideólogos do liberalismo e iluminismo que tanto influenciaram a forma de pensar, agir e educar o mundo ocidental. Conforme explicou Michel de Certeau:

Umbrales. México: Siglo Veintiuno Editores, 2001, p. 137. Outros autores enquadram prefácios na categoria protocolos de leitura. Ver: SHOLES, Robert. Protocolos de leitura. Lisboa: Edições 70, 1991. CHARTIER, Roger. A história cultural: entre práticas e representações. Lisboa: Difel, 1990. DERRIDA, Jacques. La dissémination. Paris: Éd. Du Seuil,1972.

${ }^{9}$ Cf. FARIA FILHO, Luciano Mendes de. A tradução como negócio: Rui Barbosa, tradutor do livro Lições de coisas, de N. A Calkins. In: ABREU, Márcia (org.). Leitura, história e história da leitura. Campinas: Mercado de Letras; São Paulo: ALB, 2000, p. 595-610. Nesse mesmo estudo, Luciano Mendes de Faria Filho chamou atenção para a importância das traduções de textos didáticos e de outros gêneros para a história cultural da escolarização e das culturas escolares. Afirmou ainda que, se o estudo das traduções já constitui campo de pesquisa consolidado, o mesmo não pode ser dito sobre as traduções de textos pedagógicos, inclusive nas investigações sobre o livro didático. 
[...] no século XVIII, a ideologia das Luzes queria que o livro fosse capaz de reformar a sociedade, que a vulgarização escolar transformasse os hábitos e costumes, que uma elite tivesse com seus produtos, se a sua difusão cobrisse todo o território, o poder de remodelar toda a nação. ${ }^{10}$

A crença na capacidade do texto de moldar o público leitor, portanto, envolve discussões acerca da política cultural adotada por instituições, intelectuais, educadores e políticos. As traduções de livros estrangeiros, assim, podem ser interpretadas como um capítulo a mais neste debate. Maria Lúcia Pallares-Burke ${ }^{11}$ emprega a metáfora da tradução cultural mirando o trabalho de investigação da antropologia social. A cultura do outro opera como um texto em língua estrangeira. Para ela, a atividade profissional do antropólogo, tal qual a do tradutor de textos, enfrenta dois problemas fundamentais: o da fidelidade e o da inteligibilidade. Nesse sentido, Pallares-Burke argumenta que a tradução consiste também em uma maneira de estimular a circulação de ideias e de explorar as várias possibilidades de engendrar mudanças culturais a partir da imitação de modelos estrangeiros. Para Pallares-Burke, "o estudo histórico da circulação e recepção de ideias pode aproveitar-se da metáfora da tradução, usando-a para salientar não só a ideia da criatividade na recepção, como também os dilemas e impasses envolvidos na compreensão intercultural". ${ }^{12}$

É a partir desta perspectiva que tentamos construir um quadro interpretativo acerca das publicações de manuais escolares de civismo patrocinados pelo governo federal. Os esforços de Rui Barbosa para que o Estado assumisse as despesas da tradução do livro de Calkins desdobraram-se em pelo menos outras duas publicações de educação cívica: Manual de Instrução Cívica, de Numa Droz, ${ }^{13}$ e $A$ moral para todos, de Adolpho Franck. ${ }^{14}$ Analisando-se esses dois livros, em particular os prefácios, é possível acrescentar a categoria ato político ao rol dos motivos que provocaram a tradução de livros didáticos.

O presidente da Casa da Moeda, Ennes de Souza, cuidou pessoalmente da publicação de $A$ moral para todos, escrito por Adolf Franck, de quem Ennes fora aluno no curso de Direito Natural, entre 1868 e 1869, no College de France.

\footnotetext{
${ }^{10}$ CERTEAU, Michel de. Ler uma operação de caça. In: A invenção do cotidiano. 1 . Artes de fazer. $8^{\mathrm{a}}$ ed. Petropolis: Vozes, 1994, p. 261.

${ }^{11}$ PALLARES-BURKE, Maria Lúcia. Nísia Floresta, o Carapuceiro e outros ensaios de tradução cultural. São Paulo: Hucitec, 1996.

${ }^{12}$ Idem, ibidem, p. 14-15.

${ }^{13}$ DROZ, Numa. Manual de Instrução Cívica. Rio de Janeiro: Casa da Moeda, 1890.

${ }^{14}$ FRANCK, Adolpho. Elementos da moral cívica. Rio de Janeiro: Casa da Moeda, 1893.
} 
[...] É com saudosa recordação que tenho lido e relido suas páginas profundas e inspiradas no mais santo patriotismo e na mais pura moral, e é com maior reconhecimento que pedi ao governo da república a necessária autorização para publicar e distribuir gratuitamente pelas nossas escolas e pelas corporações militares e civis de nossa pátria este fragmento de seu sublime ensino. ${ }^{15}$

Ao mencionar "a necessária autorização para publicar e distribuir gratuitamente pelas nossas escolas", Ennes de Souza não a profere por uma questão de formalismo. Indica, outrossim, um momento importante da história do livro no Brasil. A prática era obrigatória desde a Convenção de Bruxelas de 1885, reunião que estabeleceu normas sobre propriedade científica e intelectual e para troca e permuta de obras científicas e literárias entre os governos de Brasil, França, Suíça, Inglaterra, Bélgica, EUA, entre outros. Pelo acordo, era possível um governo publicar livro ou trabalho científico de outro país, desde que devidamente autorizado pelo autor e governo de origem, e publicado oficial e gratuitamente pelo governo requerente. ${ }^{16}$

Na verdade, Ennes de Souza publicou parcialmente a obra de Adolf Franck, tendo por referência, segundo ele, a tradução portuguesa feita por Cândido Figueiredo. Na edição brasileira, recebeu o título Elementos de educação cívica. No prefácio, Ennes de Souza revela parte das disputas ideológicas entre as várias correntes políticas que miravam a direção política da República. Surge, então, a ideia do civismo como a devoção ao geral e a subordinação do particular, como o conhecimento das leis que regem o país e regulam as relações entre indivíduos, grupos, entre sociedade e Estado, enfim, como caminho necessário à consolidação da República.

[...] Todas as seitas - catholica ou positivista, protestante ou judaica, musulmana ou espírita - sejam ellas quaes forem - como conjunto de ideas e sentimentos - ou são ou poderão ser mui respeitáveis, mas com a condição de permanecerem nos limites próprios às associações particulares sujeitas as leis do paiz, em ordem a respeitarem-se mutuamente uma ás outras, e não sahirem jamais dos princípios e regras da moral privada e social, das ordenações de hygiene e das exigências da ordem publica; como elemento político, porém, classificadas em classes, grupos ou castas antagônicas ou hostis á constituição

\footnotetext{
${ }^{15}$ SOUZA, Ennes de. Prefácio. In: FRANCK, Adolph, op. cit., 1893, p. 06.

${ }^{16}$ Ver: LYON, Caen; DELAIN, Paul. Lois francaise et étrangere sur la proprietè litteraire e artistique. Paris: Pichon, 1989. LIPSKYC, Delia. Derecho de autor y derechos conexos. Buenos Aires: Unesco; Cerlalc; Zavaria, 1993.
} 
e ás leis da República, não podem de modo algum ser aceitas, quanto mais substituir e menos ainda sobrepujar a idea mais geral e mais elevada do amor á pátria. ${ }^{17}$

Desta passagem depreende-se que a vertente liberal do republicanismo brasileiro, capitaneada particularmente por Rui Barbosa, concebia a educação cívica como algo além de instrumento de formação do cidadão republicano. Das palavras de Ennes de Souza sobressai nítida intenção de fazer da educação cívica arma política contra outras correntes que disputavam a hegemonia da República. Nessa arena, positivistas e jacobinos tornaram-se os adversários prediletos.

As críticas de Ennes de Souza abrangeram também temas que, segundo ele, caracterizavam o sistema político supostamente ameaçador da unidade nacional. Por isso, condenou abertamente as falcatruas eleitorais promovidas por extensa rede clientelista, desde os votantes até os eleitos, passando pela comissão eleitoral. Para ele, essa prática política era nada mais que um gesto anticívico, indicador da necessidade de se buscarem novos caminhos. Ennes de Souza atacou acidamente o clientelismo:

[...] Se um quidan desses dá um voto a qualquer candidato aos cargos de eleição, acha que é ipso fato dono de seu eleito, isto é, julga-se com direito a obter, pela acção directa ou indirecta deste, um emprego ou ao menos empenhos para alcançar o lugar ao que almeja, custe o que custar, transformando o eleito em um pedinte. ${ }^{18}$

A força do discurso cívico de Ennes de Souza produziu, sobre ele próprio, a imagem de um sério liberal. A prática política parece ter confirmado as ideias. Ennes de Souza era um verdadeiro estranho no ninho da seara clientelista que corroeu os princípios republicanos dos tempos de Rui Barbosa. Em estudo sobre as práticas clientelísticas na época em que Rui comandou o Ministério da Fazenda, José Murilo de Carvalho excluiu Ennes de Souza do círculo de "pidões" que descaracterizaram as promessas republicanas. Conforme explicou José Murilo de Carvalho, a partir da análise de cartas trocadas entre Rui Barbosa e outros funcionários:

Verdadeira avis rara, em toda correspondência, e talvez em toda a burocracia da época, é Antônio Ennes de Souza, nomeado por Rui diretor da Casa da Moeda. Ele pediu a Rui que não fizesse uma nomeação de praticante para evitar o empenho "que só consulta o interesse individual, por vezes bem ilegítimo, dos pretendentes e de seus patronos". Só

\footnotetext{
${ }^{17}$ SOUZA, Ennes de. Prefácio. In: FRANCK, Adolph, op. cit., 1893, p. 10-11.

${ }^{18}$ Idem, ibidem, p.18.
} 
se deveriam levar em conta, diz ele, provas de máxima capacidade, mais e melhores exames e prática anterior (Capital Federal, 30/09/1890). Tal posição era tão destoante que Ennes foi acusado de insano pelo oficial de gabinete de Rui, Antônio Joaquim de Souza Botafogo. A irritação de Botafogo pode ser explicada pelo fato de o candidato recusado por Ennes ser seu recomendado (Botafogo a Rui, Rio, 29/9/1890). ${ }^{19}$

O exemplo de lealdade republicana, dos princípios liberais e do amor à pátria, Ennes de Souza buscou em escritores, professores e políticos europeus. Daí afirmar que "amamos, pois, nosso país como Phocion amou a Grécia, como Numa Droz ama a Suissa, como Adolpho Franck, a França e para conseguirmos tornar em uma consunmada realidade pratica esse nobre sentimento, sigamos o ensino generoso desses verdadeiros typos de bons cidadãos". ${ }^{20}$ Note-se que os homens exemplares mencionados por Ennes de Souza são, sobretudo, políticos e escritores desempenhando papel de relevância em seus respectivos países e épocas, pelo que escreveram e pela função pública que exerceram.

Manual de Instrução Cívica, de Numa Droz, foi outro livro muito influente nas ideias da elite política. O próprio dr. Ennes de Souza, presidente da Casa da Moeda, instituição responsável por publicar o livro de Droz, reconheceu o pioneirismo do esforço empreendido pelo tradutor do livro no Brasil, dr. Domingos Nogueira Jaguaribe Filho:

Ao lado do grande serviço prestado ao paiz pelo meu prezado amigo dr. Domingos Jaguaribe com a sua tradução do bellissimo livro de Numa Droz, Manual de Instrução Cívica, seja-me, pois, licito trazer também á construção político-social da nossa republica a minha pequena pedra interessando-me por esta edição popular de alguns utilíssimos capítulos do ilustrissimo e sábio patriota francez. ${ }^{21}$

Conhecer a trajetória da publicação e do tradutor do Manual de Instrução Cívica de Droz significa percorrer uma das mais expressivas metamorfoses vivenciadas por monarquistas após o sucesso do movimento republicano. O livro foi publicado no Brasil em 1891. A tradução ficou sob a responsabilidade do dr. Domingos Nogueira Jaguaribe Filho, médico, escritor, político, sócio-fundador do Instituto Histórico e Geográfico de São Paulo,

\footnotetext{
${ }^{19}$ CARVALHO, José Murilo de. Rui Barbosa e a razão clientelista. In: Dados, 2000, vol. 43, n. 1. Rio de Janeiro, 2000, p. 11.

${ }^{20}$ SOUZA, Ennes de. Prefácio. In: FRANCK, Adolph, op. cit., 1893, p. 38.

${ }^{21}$ Idem, ibidem, p. 13.
} 
além de comendador. Chama a atenção o fato de o governo republicano atribuir a tradução de um manual escolar, publicado sob a chancela oficial, a um "republicano de última hora", como se verá adiante, e, sobretudo, a um dos 14.284 monarquistas condecorados por d. Pedro II com o título de comendador da Ordem da Rosa, insígnia atribuída somente àqueles com relevante dedicação ao Império e fidelidade ao monarca.

Dr. Domingos Jaguaribe nasceu em uma das ramificações da restrita rede de sociabilidade formada por intelectuais e políticos brasileiros. Na Província do Ceará, seu pai, Domingos Nogueira Jaguaribe, formou-se advogado e exerceu os cargos de juiz, promotor, desembargador, chefe de polícia. Na esfera política, foi deputado da Província do Ceará na legislatura 1850-1851, tendo inclusive presidido a Assembleia Legislativa, além de deputado geral do Império ininterruptamente, entre 1853 e 1870, e senador, de 1870 a 1889 . Exerceu ainda o cargo de ministro da Guerra, entre 1871 e 1872, período que coincide com a exaltação patriótica em torno da Guerra do Paraguai, tendo, inclusive, premiado Jaguaribe com a Medalha da Campanha da Guerra no Paraguai. A esta altura, Domingos Nogueira Jaguaribe havia sido condecorado pelo Império, recebendo o título de visconde de Jaguaribe e tendo-se casado com Clodes de Alencar Jaguaribe, viscondessa de Jaguaribe, concunhada do irmão do romancista e escritor José de Alencar.

Foi ao esposo da concunhada de seu irmão que Alencar dedicou o livro Iracema. No prólogo à primeira edição, de 1865, José de Alencar dirige-se a Domingos Jaguaribe com as seguintes palavras:

[...] Meu amigo,

Este livro o vai naturalmente encontrar em seu pitoresco sítio da várzea, no doce lar, a que povoa a numerosa prole, alegria e esperança do casal.

Imagino que é hora mais ardente da sesta.

O sol a pino dardeja raios de fogo sobre as areias natais; as aves emudecem; as plantas languem, a natureza sofre a influência da poderosa irradiação tropical, que produz o diamante e o gênio, as duas mais brilhantes expansões do poder criador.O livro é cearense. Foi imaginado aí, na limpidez desse céu de cristalino azul, e depois vazado no coração cheio das recordações vivazes de uma imaginação virgem. Escrevi-o para ser lido lá, na 
varanda da casa rústica ou na fresca sombra do pomar, ao doce embalo da rede, entre os múrmuros do vento que crepita na areia, ou farfalha nas palmas do coqueiro. ${ }^{22}$

Não deixa de ser sugestivo pensar no paradoxo: enquanto o visconde de Jaguaribe foi o interlocutor de uma obra ocupada em encontrar as raízes da nacionalidade, ressaltando o papel dos indígenas, o seu filho buscou traduzir da Suíça o modelo de instituições jurídico-políticas, de relações entre indivíduo, sociedade e Estado, de civismo e educação cívica a ser implantados pela República. Enquanto o saudosismo regional marca a apresentação do livro de Alencar, a atração pelo modelo suíço de sociedade levou o dr. Domingos Jaguaribe Filho a traduzir o estilo de educação cívica considerada ideal. A tradução, neste caso, extrapola a questão do idioma, avançando para as tentativas de transplantar o padrão cultural e político dos países europeus como elemento de formação da sociedade brasileira.

O currículo do pai parece ter estimulado a carreira do filho. Embalado pelo motor hereditário que movimentava a vida política brasileira, dr. Domingos Jaguaribe construiu carreira política, primeiramente, apoiado pela Sociedade Abolicionista, como deputado federal pela Província do Ceará. No Partido Conservador, tinha trânsito livre nos círculos sociais do Império. Foi eleito deputado federal representando o Ceará (1888). Sua candidatura e legislatura distinguiram-se pela opção abolicionista. ${ }^{23}$ Ele mesmo documentou parte dessa trajetória conservadora, monarquista e antiescravista. Nas cartas encaminhadas ao imperador, lê-se o engajamento do oligarca crente que o escravismo apenas onerava o Estado, impedia o desenvolvimento das fazendas e manchava a imagem do país no exterior. Em meados de 1888, queixa-se ao imperador, reivindicando o fim da escravidão como o único remédio para salvar a Monarquia. ${ }^{24}$

Noutro volume de cartas, trocado com algumas das principais lideranças abolicionistas, dr. Domingos Jaguaribe aparece em qualidades tridimensionais: mecenas da causa antiescravista, abolicionista convicto e parceiro das agonias

\footnotetext{
${ }^{22}$ ALENCAR, José de. Iracema. 1865. O prólogo à primeira edição encontra-se disponível na versão digital do livro publicado pela Biblioteca Nacional, disponível em: http://www.dominiopublico.gov.br/download/texto/bn000014.pdf.

${ }^{23}$ Registre-se que, muito embora fosse abolicionista, dr. Domingos Jaguaribe Filho expressou em muitos escritos afinidade com as concepções raciais que postulavam o branqueamento da raça brasileira por meio da imigração europeia. Cf: AZEVEDO, Célia Marinho de. Onda negra, medo branco: o negro no imaginário das elites no século XIX. 2004, p. 63-64.

${ }^{24}$ JAGUARIBE FILHO, Domingos Nogueira. Homens e ideias no Brasil. Rio de Janeiro: Typ. de G. Leuzinger \& filhos, 1889.
} 
literárias da escassa sociedade livresca do Brasil no século XIX.$^{25}$ Marco do engajamento na causa abolicionista foi a publicação do livro Os herdeiros de Caramurú, ${ }^{26}$ romance histórico publicado em 1880, dedicado ao visconde de Rio Branco. Nele, dr. Domingos Jaguaribe expôs sua visão acerca da degenerescência humana causada pelo escravismo desde os primeiros contatos entre portugueses e indígenas até a forma acabada, caracterizada pelo tráfico negreiro. Justificava, então, o seu engajamento no abolicionismo, afirmando-se "sinceramente convencido de que só há uma causa n'este mundo pela qual nos devemos interessar com todo o esforço, que é o bem do genero humano, não duvidamos escrever este humilde trabalho, vasado nos moldes de uma intenção pura e nobre."27 E conclui:

[...] as raças mestiças hão de olhar a história como um mecanismo de grandes dores e de grandes lições, e essa na mão hão de abençoar a igualdade dos homens e a união dos povos, elementos univocos, que devem servir de aspiração e de ideal aos que se interessam pelo bem do genero humano. ${ }^{28}$

Correspondências trocadas com Joaquim Nabuco, presidente da Sociedade Brasileira Abolicionista, revelam que dr. Domingos Jaguaribe esforçou-se para fazer de Os herdeiros de Caramurú ponta de lança de uma campanha de arrecadação financeira destinada ao movimento abolicionista.

[...] Londres, 16 de novembro de 1882.

Meo caro dr. Jaguaribe,

Ainda não agradeci os seus discursos na Assembleia Provincial de S. Paulo. Faço-o agora pedindo-lhe que nunca se esqueça de mandar-me os seus trabalhos. A propaganda abolicionista conta poucos servidores tão úteis, prestimosos e tão incansáveis como V.C. Falta ao Partido abolicionista, infelizmente, uma só coisa, mas essa é o mesmo das propagandas pela imprensa: Dinheiro. Talento, coração, coragem, abnegação, independência, temos: o que não temos é dinheiro. Se fossemos um partido rico podíamos encarregal-o

\footnotetext{
${ }^{25}$ No século XIX, a frágil sociedade letrada brasileira correspondeu a significativas barreiras para a ação dos escritores. A ausência do público-leitor gerou impasses e agonias em muitos intelectuais que almejaram fazer das letras mecanismo de construção de uma nova sociedade. Este tema foi estudado com muita propriedade por CANDIDO, Antônio. Formação da literatura brasileira: momentos decisivos. $6^{\text {a }}$ ed. Belo Horizonte: Ed. Itatiaia, 1981.

${ }^{26}$ JAGUARIBE FILHO, Domingos Nogueira. Os herdeiros de Caramuru: romance histórico. São Paulo: Edição do Auctor, 1880.

${ }^{27}$ Idem, ibidem, s/p.

${ }^{28}$ Idem, ibidem, p. 425.
} 
de publicar obras abolicionistas, traduções de livros como a Cabana do Pae Thomaz, essa Bíblia da emancipação dos escravos. Vidas de abolicionistas celebres, poesias como o Poema dos Escravos de Castro Alves e edições de livros como Os Herdeiros de Caramuru (sobretudo o $1^{\circ}$. volume) e de documentos da nossa História, como os papeis do trafico. Infelizmente como podemos fazer tudo isso? Admiro e applaudo a sua constancia, firmeza e convicção nessa causa e honro-me com a sua confiança.

Creia-me sempre

De V E.

Correligionário e amigo obrigado

Joaquim Nabuco ${ }^{29}$

A ideia de promover edição popular de livros abolicionistas ganhou corpo. No final de 1882, Domingos Jaguaribe doou 300 exemplares de Os herdeiros de Caramuru para a "caixa” da Sociedade Brasileira Abolicionista. Joaquim Nabuco agradeceu primeiramente os dois bilhetes da loteria do Ipiranga, oferecidos por Jaguaribe à SBA, no entanto mostrou-se pessimista quanto à possibilidade de estimular a campanha através da literatura:

[...] quanto ao assumpto da sua carta, é evidente que nós aceitamos com toda satisfação e reconhecimento o seu donativo e que se podessemos vender os 300 exemplares, muito lucraríamos fazendo uma edição popular de propaganda. Creio porém que os "herdeiros (desculpe-me ter dito "filhos", anteriormente) de Caramuru" encontrará como romance a dificuldade de venda que torna profissão literária entre nós profissão de luxo, de despesa e quasi de ostentação e não deixa ninguém viver de pena. Se acontecer todavia, o contrário, como já lhe disse, nenhuma obra despertaria mais o sentimento abolicionista do que o magnifico livro de investigação histórica e paixão humanitária que traz o seu nome. ${ }^{30}$

André Rebouças, em maio de 1883, esclareceu os rumos alcançados pelas propostas de Jaguaribe, respondendo nos seguintes termos:

[...] de conformidade com os desejos, de nosso presidente Joaquim Nabuco, acabam de criar um fundo, exclusivamente destinado a propaganda abolicionista com livros, panfletos etc. Seu generoso offerecimento de $100 \$ 000$ será a primeira cota desde fundo. A. Rebouças. ${ }^{31}$

\footnotetext{
${ }^{29}$ JAGUARIBE FILHO, Domingos Nogueira. Homenagem a Joaquim Nabuco. São Paulo: Duprat, 1909, s/p.

${ }^{30}$ Idem, ibidem, p. 11.

${ }^{31}$ Idem, ibidem.
} 
Fazer da literatura arma política não foi instrumento apenas da luta abolicionista. Dr. Domingos Jaguaribe já havia ensaiado esta forma de ação dois anos antes quando, em 1880, mesmo ano de lançamento do livro Os herdeiros de Caramuru, publicou $A$ arte de formar homens de bem-offerecida às mães de família. No prefácio asseverava: "estamos convencidos de que o maior serviço que se póde prestar à nossos cidadãos é divulgar a instrucção e conhecimento, úteis, e que, todo dinheiro gasto para este desideratum será pago com a usura em benefício no futuro". Dinheiro não era mesmo o problema para impedir Domingos Jaguaribe de publicar suas ideias. Além das cifras já referidas na questão abolicionista, esse "mecenas de si mesmo" quantificou os valores empenhados na publicação de $A$ arte de formar homens de bem:

[...] A presente edição de dous mil exemplares, que nos custou um conto e quatrocentos mil réis, é quase toda destinada à distribuição gratuita para as mães de família. Reservamos apenas quinhentos exemplares para serem vendidos e cuja produção será apllicado nas fontes do Correio (Rio Claro, Fazenda Cafezal, 26 de janeiro de 1880). ${ }^{32}$

Converteu-se ao republicanismo em junho de $1889:^{33}$ “"terminado o período fatal da escravidão, declarei-me republicano na Câmara dos Deputados, com João Manuel, Cezario Alvim e Tavares". ${ }^{34}$ Nesta transição, Jaguaribe passou a defender princípios nem sempre consensuais, como o desenvolvimento da Província de São Paulo pelo caminho da colonização, modernização e o municipalismo. Pretendia-se, mais uma vez, promover o modelo europeu de sociedade no Brasil. Os programas de colonização e modernização da Província de São Paulo validaram a hipótese. ${ }^{35}$ A reprodução social da elite brasileira e a repro-

\footnotetext{
32 JAGUARIBE FILHO, Domingos Nogueira. A arte de formar homens de bem - offerecidas às mães de família. São Paulo: Correio Paulistano, 1880, s/p.

${ }^{33}$ É muito provável que a guinada final do dr. Domingos Jaguaribe Filho tenha ocorrido na tempestuosa sessão inaugural do Gabinete Visconde de Ouro Preto a 11/06/1889. Conforme registrou Sérgio Buarque de Holanda, a sessão foi marcada pela aprovação do voto de desconfiança em relação ao novo gabinete e da conversão ao republicanismo de um liberal, Cesário Alvin, e de um conservador, o padre João Manuel. Cf: HOLANDA, Sérgio Buarque. O Brasil monárquico. vol. 7, 2005, p. 411. ${ }^{34}$ JAGUARIBE FILHO, Domingos Nogueira. Homenagem a Joaquim Nabuco. São Paulo: Duprat, 1909, p. 08.

${ }^{35}$ A participação do dr. Domingos Jaguaribe Filho na modernização do interior paulista foi analisada por: OLIVEIRA, José Oswaldo Soares de. Contribuição ao estudo das origens da ideologia do planejamento moderno no Brasil: Domingos Jaguaribe e as propostas dos núcleos coloniais: 1874-1900. Tese de doutorado, FAU, Universidade de São Paulo, 1997.
} 
dução das ideias europeias traduziram-se na tentativa de reproduzir a própria espacialidade geográfica europeia na paisagem de São Paulo.

Nesse sentido, a tradução do livro de Numa Droz (Instruction Civique: manuel cours élémentaire à l'usage dês l'écoles primaires superieures des Écoles secondaires des écoles complémentaires et des jeunes citoyens) pode ser interpretada como ato político decisivo no processo de adesão, por parte do dr. Domingos Jaguaribe Filho, ao princípio do municipalismo como cerne da organização política do país. O livro obedece à clássica ideia de que, para ser um bom cidadão, é necessário conhecer as leis que regem a nação, a lei, a justiça e o direito, enunciados como premissas essenciais do civismo. A estrutura interna do curso oferecido compõe-se de quatro partes: princípios gerais (pátria, soberania nacional, república, liberdade, igualdade, fraternidade são os temas básicos desenvolvidos); órgão e funções do Estado - basicamente o estudo da constituição de um país; o direito internacional, como mediador das relações harmônicas entre os estados; as instituições da pátria, em que, basicamente, se analisa a projeção de todos os itens anteriores na realidade suíça.

Um pequeno bilhete de Numa Droz foi arrolado como prefácio. Enquanto objeto de análise histórica do livro, e da história dos manuais didáticos, os prefácios assumem funções que vão muito além daquelas prescritas por uma história normativa da leitura. A intenção autoral não se limita a orientar professores e alunos quanto à melhor forma de manusear, ler e estudar o livro. $\mathrm{O}$ bilhete-prefácio de Numa Droz revela, ao contrário, as marcas da rede de sociabilidade da cultura letrada em diferentes nações e como os saberes educacionais circulavam em cadeia nacional. Prefácios como estes enfim expõem fios dos contextos históricos interligados à história da educação no plano mundial. Em uma palavra, demonstram que, em muitos casos, os prefácios são portadores de ricas informações sobre as coisas do mundo que envolvem o mundo do livro:

[...] Berne, 14 de junho de 1890

Senhor,

Quizestes conceder-me a honra de pedir autorisação para traduzir em portuguez, para uso das escolas do Brazil, o meu "Manual de Instruç̧ão Cívica".

É com o maior prazer que vos concedo esta autorisação, assim como vos permitto que modifiqueis o livro, conservando o espírito do qual elle provém; de modo que possaes fazer as alterações necessárias aos fins que tendes em vista.

Serei muito feliz se puder contribuir em uma fraca medida para desenvolver no coração da mocidade brazileira o sentimento de patriotismo e dedicação às ideias democráticas, 
que nos consideramos na Suissa, como os mais firmes sustentaculos de uma ordem de coisas, ao mesmo tempo estavel e progressiva.

Recebei, senhor, os protestos de minha alta consideração.

Droz. $^{36}$

De início é preciso destacar o desnível deste tipo de prefácio em sua articulação mais profunda com o teor do texto: deixa o tradutor livre para interferir no texto, desde que as modificações atendessem aos intuitos democráticos e patrióticos. Numa Droz não apenas autoriza a tradução e publicação do manual pelo governo brasileiro, como permite modificações julgadas cabíveis. É como se o autor abrisse mão da autoridade autoral, fazendo desaparecer o próprio conceito de autor, entendido não como nome próprio, mas como um agrupamento de discursos que cumpre função classificatória - "agrupa e delimita textos, exclui discursos, opõem-nos entre si, estabelece filiações etc.". ${ }^{37}$

Não obstante a opinião pessoal de Droz, o texto foi integralmente traduzido para o português. A opção pela tradução literal do texto foi explicada pelo próprio dr. Domingos Jaguaribe. No balanço histórico sobre a campanha municipalista nos anos iniciais da República, ele testemunhou que o livro foi escrito com intuito de divulgar as ideias municipalistas entre professores, educadores e estudantes paulistas. Era também uma forma de apresentar ao então presidente da Província de São Paulo, Campos Sales, as ideias de Numa Droz, considerado por Jaguaribe como o mais importante político e idealizador das questões municipalistas:

[...] Quando tivemos a honra de estar na Suissa fizemos conhecimento pessoal com este homem de Estado, actual ministro de estrangeiros, cargo que exerce há 20 annos, só tendo deixado para exercer o logar de presidente da República Suissa. Foi ultimamente connvidado para governar Creta, mas rejeitou a honra.

Como tivemos a honra de ser auctorisado por sua carta, para fazer a traducção do seu livro Manual de Instrucção Cívica, e o Governo Federal da República Brazileira mandasse imprimir, á sua custa, este livro, cuja traduç̧ão oferecemos á memória de Benjamin Constant e á mocidade brasileira, convém que seja conhecida a doutrina verdadeira, sobre o município, tal como se a interpreta na Suissa. ${ }^{38}$

\footnotetext{
${ }^{36}$ DROZ, Numa, op. cit., 1890, s/p.

${ }^{37}$ HANSEN, José. Autor. In: JOBIM, José Luis (org.). Palavra crítica. Rio de Janeiro: Imago, 1992, p. 35.

${ }^{38}$ JAGUARIBE, Filho, Domingos. O município e a República (III volume). São Paulo: Editores

J.B. Endrizzi \& Cia, 1897, p. 78.
} 
Para Jaguaribe, a tradução do Manual de Instrução Cívica foi um ato político comprometido em divulgar a doutrina suíça sobre o papel político dos municípios no interior da República. Daí o porquê evitar adaptações, subtrair capítulos ou promover outra mudança qualquer no texto. A única modificação substancial veio não da tradução, mas da introdução integral da primeira carta constitucional dos Estados Unidos do Brasil. Para além dos princípios gerais, do estudo da constituição e das relações internacionais, são as questões propostas no capítulo "As instituições da pátria" que mais revelam as nuances históricas da tradução. O que pesa é, sobretudo, a experiência histórica do autor. Numa Droz ${ }^{39}$ nasceu em La Chaux-de-Fonds, Suíça, no ano de 1844. Autodidata, tornou-se professor aos 21 anos, após dura fase juvenil com trabalhos prestados no comércio e outros por toda a infância e adolescência. Membro do Partido Radical Liberal, tornou-se parlamentar dedicado à defesa de teses polêmicas. Assim, militou contrariamente à criação, em 1870, do Banco Central Suíço, por considerar o ato um fenômeno intervencionista de franca oposição aos mecanismos liberais de condução dos negócios públicos. Com a mesma disposição atuou em prol da separação entre Estado e Igreja, escrevendo a lei de laicização do estado e da educação. As credenciais políticas de Numa Droz dão conta de um educador e político profundamente conhecedor da organização política da Suíça. Não por outro motivo, por duas vezes chegou ao grau mais alto da representação política da federação, o de conselheiro geral do Parlamento, em 1881 e 1887.

Foram nas ideias liberais desse quadro liberal que dr. Domingos Jaguaribe inspirou-se para discutir o propósito de organização política e de educação cívica. O livro havia sido lançado em 1884 sob o título Instruction Civique: manuel cours élémentaire à l'usage dês l'écoles primaires superieures des Écoles secondaires des écoles complémentaires et des jeunes citoyens. Nas mais de 230 páginas lê-se a estrutura administrativa e política da Suíça. Destaca-se a peculiaridade da federação helvética e sua base acentuada no poder local, isto é, municípios e cantões. É o modelo de democracia representativa baseado nas eleições distritais, conferindo ênfase na participação dos cidadãos na comunidade política a partir da esfera local.

Se o livro sobre a instrução cívica na Suíça foi mantido integralmente, acrescido apenas da Constituição republicana, o mesmo não pode ser dito em relação

\footnotetext{
${ }^{39}$ Sobre a biografia política de Numa Droz ver: ALTTERMATT, URS. Conséil Fédéral: dictionaire biographique des cents primiers conseillers féderaux. Fribourg: Cabétia, 1993, p. 218-221. (Colection Archives Vivantes)
} 
ao pensamento político de Domingos Jaguaribe. As ideias traduzidas tornaramse diretrizes para suas ações políticas e o municipalismo defendido por Numa Droz tornou-se a principal bandeira do republicano de última hora, levando-o a querer instituir no Brasil a estrutura política que antes traduzira como manual de instrução. Tudo indica que o texto traduzido, inicialmente para ser adotado nas escolas paulistas, tornou-se instrumento de luta nas disputas que estremeceram as relações entre os diversos grupos que procuravam dar forma à República, sobretudo em São Paulo. Nesse sentido, não satisfeito com a pouca e inócua atenção dispensada pelas autoridades políticas e educacionais do Estado de São Paulo em relação à divulgação do livro, Domingos Jaguaribe optou por publicá-lo nas páginas do jornal O Município, órgão fundado em São Paulo no ano de 1896 com a finalidade de divulgar a autonomia municipal entre os republicanos paulistas.

No contexto em que a política dos governadores, invenção política responsável por institucionalizar a República, ganhava seus mais nítidos contornos, dr. Domingos Jaguaribe Filho proclamava frases de efeito em defesa do município:

[...] Não cremos que os governos que se fortificam com a centralização, possam fazer a república ficar sendo o governo que melhor sirva ao povo; porque taes governos destróem os elementos da autonomia municipal, unicos que fortificam a educação cívica, fazendo aproximar os interesses dos cidadãos dos do município, de modo que se regula o valor delles pelo valor de cada cidadão, podendo o município representar a nação, em pequeno, e girar ao redor do Estado, como este ao redor da nação. ${ }^{40}$

Ou seja, quando a institucionalização republicana constituía apenas um teatro de incertezas, o municipalismo parece ter seduzido parte dos republicanos brasileiros, tendo sido adotado como programa por dr. Domingos Jaguaribe e alguns correligionários no Estado de São Paulo. O propósito de uma organização política republicana moldada pela autonomia municipal entrou em rota de colisão com as principais forças políticas da República. Revisitando, outra vez, o balanço histórico sobre a campanha municipalista, dr. Domingos Jaguaribe destaca um arsenal de críticas aos líderes do Partido Republicano Federal por tentarem proibir a circulação do jornal $O$ Município. As críticas à guinada centralizadora do governo federal e dos republicanos paulistas foram dirigidas principalmente a um dos principais personagens da vida política nacional:

\footnotetext{
${ }^{40}$ JAGUARIBE FILHO, Domingos Nogueira. O município e a República. São Paulo: Typografia King, 1897, p. 124.
} 
Francisco Glycério. ${ }^{41}$ Em um ácido discurso em que justificava a republicação do livro de Numa Droz através da imprensa, dr. Domingos Jaguaribe comentou a ação de Glycério contra os adeptos da autonomia municipal:

Sendo muito conveniente mostrar o valor da autonomia municipal, tivemos a honra de transcrever o livro no jornal que fundamos para a propaganda que nos custou um prejuízo real de 86 contos de réis, bem empregados, porque não tardará o tempo em que o povo deverá intervir para tornar uma realidade este grande ideal, fazendo com que os chefes actuais, sejam julgados à frente dos quais se acha o general Glycério pelo mal que tem feito. ${ }^{42}$

Assim, o encontro entre educação cívica e municipalismo foi viabilizado pelas coordenadas históricas que marcaram a crise final do reinado de Pedro II. Como se sabe, a década de 1880 foi marcada não apenas pelos movimentos finais da Monarquia, como também pelas últimas jogadas pró-Império. Em junho de 1889, em derradeiro contra-ataque, o Gabinete Visconde de Ouro Preto propôs revigorar a Monarquia, conferindo mais poderes e plena autonomia aos municípios. ${ }^{43}$ A reforma municipal, porém, foi ofuscada por um fenômeno político mais duradouro e mais representativo de nossa história política. Venceu o federalismo e, portanto, a consolidação, uma vez mais, das unidades maiores - províncias e estados - em detrimento da autonomia municipal. O coronelismo, forma política enraizada na organização política brasileira, seria, então, nada além do símbolo desse arquétipo de nossa cultura política.

No plano ideal, os livros estavam prontos para cumprir a função. No plano histórico, porém, a República era o governo das oligarquias, e os municípios, base social para a prática do coronelismo, mandonismo local etc. Processo este que só se consolidou com a ascensão de Campos Salles à presidência da República (1898-1902), quando se inaugurou no Brasil uma fase de relaxamento das tensões políticas geradas pelo federalismo republicano. Tensões que, no final de 1897, por pouco não resultaram na morte de seu antecessor, Prudente de Moraes. Ele sobreviveu, mas seu ministro da Guerra, marechal Bittencourt, não suportou

\footnotetext{
${ }^{41}$ A importância de Francisco Glycerio no movimento republicano e na consolidação da República foi destacada por muitos autores. Gilberto Freyre, ao analisar a transição da Monarquia à República e comentar as contradições em torno das forças políticas instauradoras da República, afirmou que "o mesmo poderá dizer-se do antagonismo entre positivistas da rigidez doutrinária de Teixeira Mendes e republicanos quase sem doutrina nenhuma - apenas argutamente oportunistas - como o senador Francisco Glycério". FREYRE, Gilberto. Ordem e progresso. $6^{a}$ ed. São Paulo: Global, 2004, p. 73.

${ }^{42}$ JAGUARIBE FILHO, Domingos, op. cit., p. 79-80.

${ }^{43}$ LEAL, Victor Nunes. Coronelismo, enxada e voto. $5^{\text {a }}$ ed. São Paulo: Alfa-Ômega, 1975, p. 99.
} 
os ferimentos decorrentes dos disparos de uma garrucha no momento em que desembarcava no Distrito Federal, ironicamente, após a vitoriosa campanha militar que esmagou os sertanejos de Belo Monte. Prudente de Morais pavimentara o caminho para a paz entre governadores e poder central. As intervenções militares no Rio Grande do Sul (Revolução Federalista) e na Bahia (Canudos) aproximaram, politicamente, o governo central das oligarquias nordestinas e sulistas, traduzindo-se, durante o governo Campos Salles, no mecanismo político conhecido por política dos governadores.

Todavia, desde a publicação da Carta Constitucional de 1891, a questão da institucionalização da República permanecia latente: solavancos militares, ações jacobinas e, principalmente, a força econômica e política das oligarquias regionais impediram a estabilidade do novo regime. Tão logo tomou posse, Campos Salles deu o passo decisivo que marcaria o panorama político brasileiro até 1930: a reforma do regimento da Câmara dos Deputados, alterando a forma de composição da Comissão de Verificação, verdadeiro baluarte do condomínio oligárquico, que, garantindo o funcionamento da política dos governadores, viabilizou a institucionalização da República. ${ }^{44}$

Nesse sentido, o propósito municipalista de Domingos Jaguaribe Filho registra importante capítulo da história política de São Paulo, na medida em que apresenta outra faceta do republicanismo e das dissensões existentes nas elites oligárquicas. Os lugares pareciam estar longe das ideias. A realidade da história política brasileira, portanto, estava distante da possibilidade de fazer do poder local base principal da soberania popular.

Em setembro de 1896, Jaguaribe articulou, junto à Câmara dos Vereadores do município de São Simão, o Congresso das Câmaras Municipais da Província de São Paulo. No texto que introduz a republicação da ata da sessão preparatória ao encontro, Jaguaribe não deixa nenhuma dúvida em relação a favor de que e contra quem o evento se realizava:

A pressão exercida pelos chefes para tirar toda a importância dos municípios, o facto de não querer a imprensa partidária dar notícias d'elles, são documentos dos tempos em que vivemos e bem podem servir de reflectores.Toda via foi Deus servido que o molde ficasse traçado e o tempo e a liberdade hão de encaminhar os princípios para a caudal da verdadeira democracia, quando Ella pode ser illuminada pela razão e não pela paixão, visto que a democracia sem luzes é um flagelo. ${ }^{45}$

\footnotetext{
${ }^{44}$ LESSA, Renato. A invenção republicana. Rio de Janeiro: Topbooks, 1999, p. 226.

${ }^{45}$ JAGUARIBE FILHO. O município e a República, op. cit., p. 210.
} 
O evento previa reunir representantes de 18 cidades. Apenas três compareceram munidas de procuração representando outras cinco, ou seja, estiveram presentes de fato, enviando representantes, apenas quatro municípios.

No encontro avaliou-se quão deturpadas as ideias do republicanismo federativo foram pelos homens públicos brasileiros. Argumentou-se que, enquanto a Constituição brasileira seguia o modelo norte-americano, a prática política simulava o parlamentarismo imitativo da república unitária do tipo francês. O município seria, então, a única forma de fazer valer a máxima da república democrática ocidental do “'governo do povo pelo povo', melhor meio de acabar com a política como profissão e meio de vida, que foi fazendo a ruina de muitos paizes, é dar a direção da sociedade aos municípios, que devem servir de célula mae de todo o systema político". ${ }^{46}$

Propôs-se, então, o municipalismo como redenção da República, um governo nacional constituído por uma federação de municípios e a formação do Partido Republicano Municipal como articulador desses princípios, pois se acreditava que somente o encontro entre município e república seria capaz de salvar a República:

[...] O sentimento de dever assegurará á republica a educação cívica de que ella carece para que seus filhos deixem de ser políticos de profissão para se fazerem patriotas sem ambições políticas. A vida municipal faz com que a liberdade crie raízes nos lugares onde ella mais precisa florescer e frutificar. ${ }^{47}$

O manifesto final foi publicado em 7 de setembro de 1896, assinado por Domingos Jaguaribe, João de Rocha Miranda e Leônidas Sá. Parece mesmo que queriam fazer do Dia da Independência, marco de refundação da República. O programa político defendia a realização de apenas uma eleição em todo o território nacional a cada três anos, além de propor a supressão do Congresso Nacional e da Presidência da República como esfera política:

[...] Que só se faça no Brasil uma eleição de 3 em 3 anos, a eleição municipal;

Que nessa eleição fique compreendido todo o mecanismo de governo, tal como os eleitores do presidente da república e dos estados, os representantes do povo e dos estados;

Que os municípios escolham um dentre delles, em cada cidade a fim de ir a capital do Estado fazer as leis e os orçamentos, e que sejam substituídos os ministros, filhos da politicagem, pelos directores dos respectivos ministérios, que serão os verdadeiros chefes das repartições;

\footnotetext{
${ }^{46}$ JAGUARIBE FILHO. Idem, p. 19.

${ }^{47}$ Idem, ibidem, p. 132.
} 
Que suprimidos os congressos (camara e senado), feitos por força de verdadeiras forças eleitorais em que os chefes políticos colocam os apaniguados, venhão os eleitos do povo, sem preocupação de fazer política;

Que os eleitos, reunidos na capital do Estado, escolham oito entre si, para do Brasil, representando três delles os Estados, que os enviam alli, e cinco os municípios dos quais se compõe os estados. ${ }^{48}$

A proposta arquitetada por Jaguaribe pode ser considerada versão brasileira da organização social e política da Suíça, escrita por Numa Droz na terceira parte do Manual de Instrução Cívica. Refletindo, anos mais tarde, sobre a força da centralização na estrutura política brasileira, o dr. Domingos Jaguaribe Filho publicou, no livro O município e a República, ${ }^{49}$ a seguinte afirmação: "em toda essa tendência absorvente dos amigos da centralização se percebe o desejo de reduzir os municípios a meros agentes da política, para obedecerem às chapas que se organizam no centro". ${ }^{50}$

Assim, dr. Jaguaribe encerrou sua sinuosa trajetória política buscando o conforto das ideias políticas em uma das mais estáveis e peculiares democracias liberais do mundo ocidental. Conservador durante a monarquia, abolicionista engajado, republicano de última hora, abandonou a vida política tão logo a proposta de descentralização do poder esbarrou na política dos governadores. A derrota das ideias políticas traduzidas por dr. Domingos Jaguaribe seriam, então, uma mostra da inadequação do municipalismo à cultura brasileira?

Não se trata disso. Roberto Schwarz ${ }^{51}$ afirmou sobre a impossibilidade de qualquer ideia política iniciar do zero. Quando tratadas pragmaticamente de um ponto de vista estético e político, a cópia inclusive liberta da "mitológica exigência da criação a partir do nada". Nesse sentido, a plataforma municipalista de Domingos Jaguaribe Filho correspondeu a uma das cópias possíveis existente no repertório de modelos políticos originados a partir da Europa Ocidental. Basta lembrar que a organização da República Federativa adotada no Brasil foi também inspirada em padrões estrangeiros de sociedade, em particular o norte-americano e o francês. As explicações para o insucesso do municipalismo, portanto, devem ser buscadas não no fato de ser uma cópia, mas sim na forma

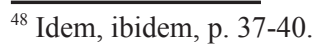

${ }^{49}$ Livro dedicado "À sua santidade papa Leão XIII".

${ }^{50}$ LEAL, Victor Nunes, op. cit., 1975, p. 100, nota 106.

${ }^{51}$ SCHWARZ, Roberto. Nacional por subtração. In: op. cit., p. 136.
} 
como saberes, ideias e outros gêneros da produção cultural circularam e foram apropriados naquele período.

É preciso considerar, então, que traduções culturais envolvem a recepção das ideias traduzidas, isto é, princípios, propostas, projetos e ideias produzidos em outra cultura precisam encontrar uma cultura disposta a recebê-los. Reportando-se a Michel de Certeau, podemos concluir que, ao ler, interpretar e traduzir para a língua portuguesa o livro de Numa Droz, dr. Domingos Jaguaribe Filho fez valer a autonomia do leitor. ${ }^{52}$ Sua condição pessoal e social permitiu lançar a questão municipal nos debates e disputas em torno da consolidação republicana. Entretanto, no interior da reduzida sociedade letrada brasileira a que pertencia, sua posição era ainda mais minoritária. Ao ler, interpretar e traduzir imaginou poder criar uma nova situação sociocultural e uma nova organização política no Estado de São Paulo e no país. Todavia, as ideias traduzidas e a sociedade imaginada por Jaguaribe Filho não se tornaram inteligíveis na cultura política do início da República. Em uma sociedade majoritariamente composta por analfabetos, a modelação da sociedade republicana foi realizada não pelos livros, mas sim pelos símbolos. ${ }^{53}$

Assim, à crença no municipalismo como alicerce da ideia republicana, defendida por dr. Domingos Jaguaribe, talvez restassem os aplausos do funcionário público, positivista e ex-membro da Escola Militar, Inácio Costa, personagem fictício do romance Numa e Ninfa, publicado por Lima Barreto em $1915 .{ }^{54} \mathrm{Na}$ ficção narrada por Barreto, corria na Câmara dos Deputados intenso debate acerca da criação de um novo Estado na federação, o Estado Guaxupé. Alguns viram na proposta um importante passo em direção ao desenvolvimento do país. Quanto mais descentralizado, melhor, mais eficaz a administração pública. Outros entenderam que a proposta seria um descalabro aos cofres públicos: quanto maior, mais cargos públicos e mais apadrinhamentos. De tão acalorado, descreveu Barreto, o debate conseguiu despertar pronunciamentos até mesmo dos mais mudos parlamentares, como o deputado Numa Pompílio de Castro. Numa, até então sempre quieto, seguindo orientação do chefe partidário, opôs-se ao projeto. Desse modo, narrou Barreto, ao menos uma virtude o debate sobre a criação do Estado de Guaxupé trouxe: revelou um grande orador:

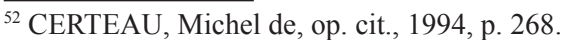

${ }^{53}$ Ver a esse respeito: CARVALHO, José Murilo de. A formação das almas. São Paulo: Companhia das Letras, 1990.

${ }^{54}$ Publicado inicialmente em folhetim no jornal Noite, conforme BARBOSA, Francisco de Assis. $A$ vida de Lima Barreto. $6^{\text {a }}$ ed. Rio de Janeiro: José Olimpio; Brasília: MEC/Inep, 1991, p. 231-235.
} 
[...] A sua argumentação foi até das mais perfeitas e eruditas, sem que a erudição perturbasse a concatenação, a seriação lógica da tese a demonstrar. Mostrou que a nossa federação não atendia a tradições locais de costumes, de língua ou de história, que não foram pequenos países que se uniram por ter um liame comum, mas, tão somente, um imenso país que se dividiu e procurou com uma mais ampla autonomia local, perfeição administrativa: e, assim sendo, não se compreendia nem o "patriotismo estadual" nem a existência de desmedidos Estados, verdadeiros impérios. ${ }^{55}$

A fé na ciência, nas leis, levou Inácio Costa a dizer, em frase que bem poderia, ironicamente, ser redirecionada a Numa Droz e ao dr. Domingos Jaguaribe, respondendo ao bilhete-prefácio que o primeiro escreveu ao segundo, arrolado na tradução de Instruction Civique: manuel cours élémentaire à 1'usage dês l'écoles primaires superieures des Écoles secondaires des écoles complémentaires et des jeunes citoyens:

[...] Meu caro dr. Numa, gostei imensamente do seu discurso. Para mim, achei nas suas palavras um bálsamo tranquilizador e patriótico. Estávamos voltando muito ao carrancismo egoísta dos conselheiros monárquicos. Os princípios republicanos estavam sendo esquecidos. Precisamos sempre reavivá-los". ${ }^{56}$

\section{Referências bibliográficas}

ALENCAR, José de. Iracema. Rio de Janeiro: MEC/INL, 1965 (Edição de centenário).

ALTTERMATT, URS. Conséil Fédéral: dictionaire biographique des cents primiers conseillers féderaux. Fribourg: Cabétia, 1993, p. 218-221. (Colection Archives Vivantes)

AZEVEDO, Célia Marinho de. Onda negra, medo branco: o negro no imaginário das elites no século XIX. São Paulo: Annablume, 2004.

BARBOSA, Francisco de Assis. A vida de Lima Barreto. $6^{\text {a }}$ ed. Rio de Janeiro: José Olimpio; Brasília: MEC/Inep, 1991.

BARRETO, Lima. Numa e Ninfa. Rio de Janeiro: Gráfica Editora Brasileira, 1950.

BERT, Paul. L'education civique. Paris: Libraire Picard - Berheim, 1882.

BITTENCOURT, Circe Maria Fernandes. Livro didático e conhecimento histórico:

\footnotetext{
${ }^{55}$ BARRETO, Lima. Numa e Ninfa. Rio de Janeiro: Gráfica Editora Brasileira, 1950, p. 03. Esta edição encontra-se disponível na versão digital do livro publicado pela Biblioteca Virtual da Universidade de São Paulo, disponível em: http://www.dominiopublico.gov.br/download/texto/bv000156.pdf. ${ }^{56}$ Idem, ibidem, p. 04.
} 
uma história do saber escolar. Tese de doutorado, FFLCH-USP. São Paulo, 1993.

CANDIDO, Antônio. Formação da literatura brasileira: momentos decisivos. $6^{\mathrm{a}}$ ed. Belo Horizonte: Ed. Itatiaia, 1981.

CARNOT, Havin; SIMON, Jules. L'instruction populaire en France. Paris: Biblioteque Liberale, 1877.

CARVALHO, José Murilo de. A formação das almas: o imaginário da República no Brasil. São Paulo: Companhia das Letras, 1990.

CARVALHO, José Murilo de. Rui Barbosa e a razão clientelista. In: Dados 2000, vol. 43, n. 1. Rio de Janeiro, 2000.

CARVALHO, José Murilo de. Cidadania no Brasil: o longo caminho. $4^{\mathrm{a}}$ ed. Rio de Janeiro: Civilização Brasileira, 2003.

CERTEAU, Michel de. Ler uma operação de caça. In: A invenção do cotidiano. 1. Artes de fazer. $8^{\mathrm{a}}$ ed. Petropolis: Vozes, 1994.

CHARTIER, Roger. A história cultural: entre práticas e representações. Lisboa: Difel, 1990.

DERRIDA, Jacques. La dissémination. Paris: Éd. Du Seuil, 1972.

DROZ, Numa. Manual de Instrução Cívica. Rio de Janeiro: Casa da Moeda, 1890.

FARIA FILHO, Luciano Mendes de. A tradução como negócio: Rui Barbosa, tradutor do livro Lições de coisas, de N. A Calkins. In: ABREU, Márcia (org.). Leitura, história e história da leitura. Campinas: Mercado de Letras; São Paulo: ALB, 2000.

FREYRE, Gilberto. Ordem e progresso. 6a ed. São Paulo: Progresso, 2004.

FRANCK, Adolpho. Elementos da moral cívica. Rio de Janeiro: Casa da Moeda, 1893.

GENNETE, Gérard. Umbrales. México: Siglo Veintiuno Editores, 2001.

GLEZER, Raquel (coord.). Catálogos do gabinete de trabalho de Prudente de Morais. São Paulo: Polo Editora, 2003.

GUIMARÃES, Hélio de Seixas. Os leitores de Machado de Assis: o romance machadiano e o público de literatura no século XIX. São Paulo: Edusp; Nankin, 2004.

HANSEN, José. Autor. In: JOBIM, José Luis (org.). Palavra crítica. Rio de Janeiro: Imago, 1992, p. 11-39.

HOLANDA, Sergio Buarque. Raízes do Brasil. Rio de Janeiro: JoséOlympio, 1956,p. 15.

HOLANDA, Sergio Buarque. O Brasil monárquico, v. 7: do Império à República. $7^{\mathrm{a}}$ ed. Rio de Janeiro: Bertrand Brasil, 2005.

JAGUARIBE FILHO, Domingos Nogueira. A arte de formar homens de bem offerecidas às mães de família. São Paulo: Correio Paulistano, 1880.

JAGUARIBE FILHO, Domingos Nogueira. Homenagem a Joaquim Nabuco. São Paulo: Duprat, 1909.

JAGUARIBE FILHO, Domingos Nogueira. Homens e ideias no Brasil. Rio de 
Janeiro: Typ. de G. Leuzinger \& filhos, 1889.

JAGUARIBE FILHO, Domingos Nogueira. O município e a República. São Paulo: Typografia King, 1897.

JAGUARIBE FILHO, Domingos Nogueira. Os herdeiros de Caramuru: romance histórico. São Paulo: Edição.

JANOTTI, Maria de Lourdes Mônaco. Dialogo convergente: políticos e historiadores no início da República. In: FREITAS, Marcos Cezar (org.). Historiografia brasileira em perspectiva. $4^{\mathrm{a}}$ ed. São Paulo: Contexto, 2001, p. 119-143.

LAPA, José Roberto do Amaral (org.). História política da República. Campinas: Papirus, 1990.

LEAL, Victor Nunes. Coronelismo, enxada e voto. $5^{\text {a }}$ ed. São Paulo: Alfa-Ômega, 1975.

LESSA, Renato. A invenção republicana. Rio de Janeiro: Topbooks, 1999.

LYON, Caen; DELAIN, Paul. Lois francaise et étrangere sur la proprietè litteraire e artistique. Paris: Pichon, 1989.

LIPSKYC, Delia. Derecho de autor y derechos conexos. Buenos Aires: Unesco, Cerlalc, Zavaria, 1993.

OLIVEIRA, José Oswaldo Soares de. Contribuição ao estudo das origens da ideologia do planejamento moderno no Brasil: Domingos Jaguaribe e as propostas dos núcleos coloniais: 1874-1900. Tese de doutorado, FAU, Universidade de São Paulo, 1997.

PALLARES-BURKE, Maria Lúcia. Nísia Floresta, o Carapuceiro e outros ensaios de tradução cultural. São Paulo: Hucitec, 1996.

PIMENTA, Antônio Martins de Azevedo. A nova capital federal e o planalto central do Brasil. $2^{\mathrm{a}}$ ed. Fac-similada. Brasília: Thesaurus, 1985.

QUEIROZ, Suely Robles Reis de. Os radicas da República: Jacobinismo, ideologia e ação. 1893-1897. São Paulo: Brasiliense, 1986.

SILVEIRA, Rosa Maria Godoy. Republicanismo e federalismo (1889-1902): Um estudo da implantação da República no Brasil. Brasília: Senado Federal, 1978.

SCHWARZ, Roberto. Cultura e politica. $2^{\mathrm{a}}$ ed. Rio de Janeiro: Paz e Terra, 2005.

SHOLES, Robert. Protocolos de leitura. Lisboa: Edições 70, 1991.

VIOTTI, Emilia. Da Monarquia à República: momentos decisivos. São Paulo: Grijalbo, 1977.

Recebido: maio/2008 - Aprovado: junho/2009. 